\title{
The Fungistatic Effect of Plant Extracts Against Monilinia fructigena (Aderhold Et Ruhl) Honey Ex Whetzel as Causal Agent of Brown Rot
}

\author{
Radu Alexandru GROZA ${ }^{1}$, Carmen Emilia PUIA ${ }^{1 *}$ \\ ${ }^{1}$ Faculty of Agriculture, Department of Environmental and Plant Protection, University of Agricultural \\ Sciences and Veterinary Medicine, Manastur Street, No. 3-5, 400372, Cluj-Napoca, Romania \\ * corresponding author: carmen.puia@yahoo.com
}

Bulletin USAMV series Agriculture 72(1)/2015

Print ISSN 1843-5246; Electronic ISSN 1843-5386

DOI 10.15835/buasvmcn-agr: 11191

\begin{abstract}
Whereas it is generally acknowledged that the use of pesticides has large benefit to farmers, the present use of pesticides in agriculture also causes negative environmental effects to society. These negative effects demand an alternative solution for conventional pesticides. Plant extracts is a group of substances extracted from different parts of plants which contain compounds with antimicrobial properties. By using the „poisoned food technique” we've managed to study the effect of plant extracts on inhibiting the growth of Monilinia fructigena, the most effective extracts were those of Echinacea purpurea, Cynara scolymus, Salvia officinalis, Tagetes sp., Hyssopus officinalis, Artemisia absinthium, Hypericum perforatum, Aristolochia clematitis and Achillea millefolium.
\end{abstract}

Keywords: extracts, fungistatic, Monilinia, pesticides.

\section{INTRODUCTION}

Monilinia fructigena (Aderhold et Ruhl) Honey ex Whetzel commonly referred to as ,apple brown rot" is the most common Monilinia species on apple and pear in Europe (Jones and Aldwinckle, 1990). The negative effects of conventional pesticides demand an alternative solution (Sokovic Marina et al., 2013).

\section{AIMS AND OBJECTIVES}

Considering the fact that apple brown rot is a disease that can cause significant damage and there are used high doses of pesticides, the aim of this study was to find some alternative solutions to conventional treatments.

\section{MATERIALS AND METHODS}

The pathogen was isolated from mummified apple fruits collected from the experimental plot by using standard phytopathological isolation techniques. Fragments of mummified tissues were surface sterilized by immersion in potassium permanganatesolutionfortwo minutes, then placed on sterile Malt-Agar medium in Petri dishes and incubated. The obtained isolate were subcultured on Malt-Agar medium for 7 days at $25^{\circ} \mathrm{C}$ (Hrustic Jovana et al., 2012). The hydroalcoholic extracts used were obtained from 18 species of plants. For testing the fungistatic effect of plant extracts the „poisoned food technique” was used (Johnson and Sekhar Chandra, 2012). In order to observe the fungistatic effect of the hydroalcoholic extracts, the colonies developed on Petri dishes were daily measured by diameters and the colony area was calculated (Hrustic Jovana et al., 2012).

\section{RESULTS AND DISCUSSIONS}

The inhibitory effect of plant extracts on pathogen Monilinia fructigena is shown in Tab. 1. On 16 and 17 days after inoculation on sterile Malt-agar medium, the colony area increased on studied variants, the difference between the average area of the first day of growth and the average area of the last day of observation is very significant positive (Tab. 1). 
Tab. 1. The growth rate of Monilinia fructigena colonies

\begin{tabular}{ccccc}
\hline Measurements & $\begin{array}{c}\text { Colony area } \\
\left(\mathrm{mm}^{2}\right)\end{array}$ & \% to control & $\begin{array}{c}\text { The difference } \\
\text { to control }\end{array}$ & $\begin{array}{c}\text { The significance } \\
\text { of the difference }\end{array}$ \\
\hline Day 2 & 3.14 & 100.0 & 0.00 & Control \\
\hline Day 6 & 5.93 & 188.8 & 2.79 & - \\
\hline Day 11 & 16.17 & 514.8 & 13.03 & $*$ \\
\hline Day 16 & 54.66 & 1740.8 & 51.52 & $* *$ \\
\hline Day 17 & 91.38 & 2910.2 & 88.24 & \\
\hline LSD (p 5\%) 45.51 & LSD (p 1\%) & 59.99 & LSD (p 0.1\%) & 77.23 \\
\hline
\end{tabular}

Tab. 2. The influence of the plant extracts on the development of colonies of Monilinia fructigena

\begin{tabular}{ccccc}
\hline $\begin{array}{c}\text { Hydroalcoholic } \\
\text { extracts }\end{array}$ & $\begin{array}{c}\text { Colony area } \\
\left(\mathrm{mm}^{2}\right)\end{array}$ & \% to control & $\begin{array}{c}\text { The difference } \\
\text { to control }\end{array}$ & $\begin{array}{c}\text { The significance of the } \\
\text { difference }\end{array}$ \\
\hline Artemisia absinthium & 3.14 & 100.0 & 0.00 & Control \\
\hline Armoracia rusticana & 3.67 & 116.7 & 0.53 & - \\
\hline Carum carvi & 64.63 & 2058.3 & 61.49 & - \\
\hline Echinaceae purpurea & 3.14 & 100.0 & 0.00 & $* *$ \\
\hline Rumex patientia & 262.00 & 8343.9 & 258.86 & $*$ \\
\hline Cynara scolymus & 28.89 & 920.0 & 25.75 & - \\
\hline Ocimum basilicum & 209.91 & 6685.1 & 206.77 & - \\
\hline Allium ursinum & 3.87 & 123.4 & 0.73 & - \\
\hline Calendula officinalis & 4.56 & 145.1 & 1.42 & - \\
\hline Allium sativum & 6.83 & 217.6 & 3.69 & - \\
\hline Salvia officinalis & 3.14 & 100.0 & 0.00 & - \\
\hline Tagetes sp. & 3.14 & 100.0 & 0.00 & - \\
\hline Hyssopus officinalis & 3.14 & 100.0 & 0.00 & - \\
\hline Achillea milefolium & 3.14 & 100.0 & 0.00 & - \\
\hline Hypericum perforatum & 3.14 & 100.0 & 0.00 & - \\
\hline Aristolochia clematitis & 3.14 & 100.0 & 0.21 & 0.63 \\
\hline Mentha piperita & 3.35 & 106.7 & LSD (p 0.1\%) 279.01 \\
\hline Lippia citrodora & 3.77 & 120.0 &
\end{tabular}

The most effective extracts for inhibiting the growth of Monilinia fructigena can be seen in Tab 2 , with the colony area of $3.14 \mathrm{~mm}^{2}$. The reduced effectiveness in the inhibition of the pathogen had the extracts of Ocimum basilicum and Rumex patientia, the average areas of the colonies treated with these extracts were higher than the average area of the colony treated with the extract of Artemisia absinthium (control), differences statistically assured (Tab 2). Tagetes spp. and Ocimum basilicum extracts were used in the control of pathogen Monilinia spp. by Teodorescu Georgeta et al. (2010), Lopez-Reyes et al (2013).

\section{CONCLUSION}

In vitro, the degree of inhibition was different depending on the hydroalcoholic extracts used, but all in all, half of the natural extracts tested had a good efficiency on inhibiting the growth of Monilinia fructigena.

\section{REFERENCES}

1. Hrustic J, Grahovac M, Mijajlovic M, Delibasic G, Ivanovic M, Nikolic M, Tanovic B (2012). Molecular Detection of Monilinia fructigena as Causal Agent of Brown Rot on Quince. Pestic Phytomed. 27(1):15-24.

2. Johnson M, Sekhar C (2012). Principles of Plant Pathology. Practical Manual. PATH 271.

3. Jones AL, Aldwinckle HS (1990). Brown rot diseases. Compedium of Apple and Pear diseases. American Phytopathology Society Press:100.

4. Lopez-Reyes JG, Spadaro D, Prelle A, Garibaldi A, Gullino ML (2013). Efficacy of plant essential oils on postharvest control of rots caused by fungi on different stone fruits in vivo, Journal of Food Protection 76(4):631-639.

5. Sokovic M, Glamoclija J, Ciric A (2013). Natural Products from plants and Fungi as Fungicides. InTech.

6. Teodorescu G, Marin FC, Sumedrea M, Murariu F (2010). Preliminary results regarding the effect of vegetal extracts on storage diseases, Research Institute for Fruit Growing, Pitesti. 